\title{
INTERDEPENDENCE IN URBAN SYSTEMS: THE URBAN CONSEQUENCES OF THE GROWTH OF HIGHER EDUCATION AND RESEARCH IN SWEDEN
}

\author{
Olof Wärneryd \\ Department of Social and Economic Geography, Lund University, \\ Sölvegatan 10, 22363 Lund, Sweden \\ e-mail: olof.warneryd@keg.lu.se
}

\begin{abstract}
This study suggests that history may repeat itself, especially in the context of ideas as, for example, in the concept of interdependence in urban systems. The background to the study is that there have been three main phases of development in the Swedish urban system: the first in the 1950s and 60s was a period of growth with a strong hierarchical component, focused on the bigger cities; the second was a phase of relative decline in the cities, with the growth of suburban and urbanized regions; the current trend, since the mid 1980s is another phase of growth in those centres that have higher educational institutions which have been deliberately spread throughout the system. This has led to the 'saving' of many towns that would probably have declined. Today we may be seeing the emergence of a new phase of change related to what may be called 'cosmopolitan interdependence' in which cities are linked into wider international patterns of interconnection. This study draws attention to some of the main components of these changes, set in an historical context. It emphasizes how increasing flows of persons, goods, information, transactions, etc., have deepened the dependence between regions and cities, which has led to the strengthening of the urban system through the greater interdependence of its parts and demonstrates the increasingly important role of higher education in our urban system. Hence the concept of interdependence should be seen as important a concept as ever in our study of urban systems, although in new forms.
\end{abstract}

Key words: Urban system, interdependence, higher education

\section{INTRODUCTION}

The rapid advance of new technologies, especially our new communication systems, has led many to cast doubt upon the utility of old geographical ideas and patterns of relationships and mutual dependence between cities and regions. However we need to be careful about abandoning older ideas, as they may still be relevant in rather different contexts. Indeed it 
may be time to reconsider the utility of some of the old ideas about interdependence within urban systems that were so popular in the 1960s. The origin of the ideas to be discussed in this paper comes from the work on interdependence in the urban system that I was involved in during the 1960s (Wärneryd 1968). Since it is very often said that most people during a lifetime can develop at most one "good" idea (some manage two!), it seems appropriate to stick with the good idea with which I was involved; this is the idea of interdependence in urban systems.

My first major project took place within a nation-wide research programme called "The Urbanization Process", which in the middle of the 1960s received a generous sum of money from the Tercentenary Fund of the Bank of Sweden. The initiators of the programme, and my own source of inspiration and supervision, came from two professors: Sven Godlund and Torsten Hägerstrand. This programme also provided a strong influence on the discipline of Geography for many years. New concepts, models and exciting theoretical thoughts were developed, and many very good empirical studies were also carried out. Unfortunately, nobody has tried to amalgamate all the findings of the ten years research programme into a comprehensive overview. But what we have found out was that in the 1960s there was a strong hierarchical structure in Sweden, for almost all kind of organizations, both private and public, favoured the national capital and other large cities. However, the growth of the public sector during the second phase, during the 1970s and 1980s, gave a different structure. Public service was required to be the same all over the country in order to support the welfare state. This meant that most cities and central places in Swedish communes grew through the employment of more qualified people in the public sector. This different process of development saved many parts of the urban system that were in decline. A third phase has now taken over. Although the public sector as a whole - particularly the health and care sector, the military system, the nine-year school, the secondary school and the administrative bodies - has seen drastic reductions in the number of employees, a new driving force in society has taken place. This has been the expansion of higher education and research, which has led to the "saving" of many cities and towns, but may now be creating a rather different role linked to increased internationalism, providing a new phase of interdependence between Swedish towns and the world at large.

\section{CONCEPTS OF INTERDEPENDECE IN URBAN SYSTEMS: STILL VALID OR JUST A NOSTALGIC TRIP?}

"Every part of the systems is so related to every other part that a change in a particular part causes a change in all the other parts and in the total system" (Young 1964, p. 64ff.)

The question that must be asked is whether the old ideas of interdependence in urban systems are still valid. To what extent does history (like old professors) repeat itself (themselves)- perhaps not in the content, in the sense of the types of activities, but in the form and relationships of the urban system. If this is the case then the mutual dependence between cities and regions may be seen as a continuing process, and may even be expanding in the contemporary period, especially with greater transnational linkages. But since 
interdependence occurs in new guises the urban system is influenced in many different ways. Indeed, Young's definition of interdependence quoted above, may not only be valid for urban systems, but may be another truism of "monumental proportion" as Roger Lee noted in The Dictionary of Human Geography (1983). But, Lee also adds that the concept of interdependence is important because it enables us to mirror and analyse the different conditions in geographical areas caused by the increased or decreased interdependence that can be measured in a number of ways.

Such interpretations suggest that the concept is still useful to the study of urban systems and may help us in our understanding of cities in contemporary society. However it must be acknowledged that much has been said about interdependence since my original research in the 1960s. Let me just refer to one of the latest and most interesting books written by the British sociologist, John Urry, in his work "Global Complexity" (2003). In the book he equates global interdependence with global complexity (p.102). Urry treats interdependence as the basic measure within the analysis of global systems and globalisation - although the last concept not even invented in the 1960s. He argued that "Global systems can be viewed as interdependent, as self-organizing and as possessing emergent properties" and suggested that we need to "examine a range of non-linear, mobile and un-predictable 'global hybrids' always on the 'edge of chaos'"(p.14). Examples of global hybrids include informational systems, automobility, global media, world money, the internet, climate change, the oceans, the ozone areas, health hazards and so on. Urry suggested that the study of these hybrids should involve "examining their dynamic interdependencies via complexity, their emergent properties can be effectively understood" (p.18). I believe these are very useful ideas, that can be used to extend our knowledge of interdependence, espe-cially in urban systems, but wish to add "Higher Education and Research" to the list of global hybrids, for the almost explosive expansion of higher education and research in Sweden has not only altered the relative growth of places but has created new patterns of interdependence. Hence the aim of this study is to elucidate two themes.

First, to what extent can the location and growth of higher educational institutions be seen as a third shaping factor in the process of increased interdependence in society in Sweden since Second World War, rather than being seen simply as a strong contemporary force of urban growth.

Second, what are the major consequences for regional development and balance in Sweden; what is likely to happen with higher education as an urban generator in the future;

Third, do these trends have new implications for linking the Swedish system more closely to the world system?

Before focusing on these themes, some brief facts about the early expansion of higher education in Sweden are needed to provide a context for the contemporary study.

\section{HIGER EDUCATION AND REGIONAL DEVELOPMENT: A FIRST EXAMPLE FROM LUND?}

In 1666 the Swedish regency issued four documents that became the foundation of a new academy in Lund in the southern province of Skåne. Up to 1658 the province had belonged 
to Denmark, but the area was conquered by Sweden during the Thirty Years war, and as a result of Treaty of Roskilde, became the southern part of the present state of Sweden. One of the very important measures taken by King Karl X Gustav to make the county of Skåne Swedish, was to fulfil an old plan to create a new university in the area. This would create a fifth university in the Swedish realm of this period - Uppsala (Sweden), Dorpat (Estonia), Åbo (Finland) and Greifswald (Germany) - although it is worth noting that three of these nodes are in other national states today. The principal aim of the new university in Lund was to allow students from the southern provinces to become clergymen and be ordained in the Swedish Lutheran Church. Previously, these students were forced to go to the university in Copenhagen. It is worth noting that although its functional aim was basically regional, its outlook was international as benefits the term 'university'. The new university in Lund was given an international character by recruiting professors from famous universities all over Europe. However, more battles and violence took place in the province before real peace occurred. In addition, the money needed to establish the university was limited because the new king, Karl XI, had almost fleeced the Swedish people in order to cover the military expenses, whilst most of the donations that the new university had received were also confiscated. Despite a more modest start than planned, Lund University played an active role in educating a new group of students in the area, most of whom had their origins in the southern part of Sweden. In addition, the university soon acquired a good academic reputation in Europe because of its devoted and hard working professors - a feature that is still true!

In retrospect it can be argued that the establishment of Lund university was an early example of a strong regional measure designed to promote the identity and development of a region and, perhaps, was the first one in which higher education was used as the key innovation. However, the economic impact must not be exaggerated. During the two first centuries of its existence the number of students fluctuated between 50 and a 100 individuals - although the students subsequently played key roles in Swedish society. Also, they were exclusively male and did not increase in numbers until the nineteenth century. But even by 1900 the number of students had only reached 581, together with 27 permanent and 13 extra professors. By 2002, student numbers had increased enormously, to 25,900 whole year undergraduate students (53 percent women) in addition to 3,100 postgraduate students. In addition there are 1,200 students registered on network-based courses, more than 1,400 foreign students, and an additional 2,600 students on its subsidiary campus in Helsingborg. This means that in 2002 there are approximately 38,000 students studying at Lund University, and these are taught and supervised by about 1,500 academic teachers, a huge growth compared to its previous years, producing a major impact on the economy of Lund and its region.

For more than 300 years the role of a university in the policies of regional development has rarely been discussed. To most people universities were looked upon as a secluded world, as examples of ivory towers set apart from society. But at end of the 1950s the debate started about the regional role of universities. Today the addition or expansion of a university or college in a town is the most frequent request of regional development agencies, and seems an absolute necessity if towns are to survive in our new knowledge-based, post-modern network society. Indeed the expansion of higher education has been, both 
internationally and nationally, one of the fastest growing research areas in the last two decades and hundreds of research works and articles can now be found on the topic on the internet. In an early study Blom (1996) is showing with data from the beginning of the 1990s the attitudes towards higher education in peripherial regions. The local politicians are most for since, while the ordinary inhabitants are rather ignorant. One research group dealing with Swedish conditions in an international context has been working for about ten years and has produced several publications (e. g. Sörlin \& Törnqvist 2000) that contain an exhaustive reference list of international and national work. The starting point of this research was the expansion of higher education in Sweden and the role of the universities and colleges in a regional context. Although the authors have argued that the higher education effort has been too widespread, particularly the allocation of money for research, the positive effects of the university or college for the city and the region cannot be questioned. Indeed, the money transferred by the state and earmarked for higher education has in several cases been the starting-point of a new "city life" in many centres, a future-oriented process supported by many different partners. The vitality that a university gives to a city, can often be seen as being of special significance for the local industry and for hiving off new businesses (for example, as seen in the case of Luleå Technical University), or has stimulated local cultural life (as in Umeå University and others). There is no doubt that universities and colleges now produce significant effects on city growth.

\section{HIGHER EDUCATION: THE STRONGEST FORCE BEHINDE THE URBAN GROWTH TODAY}

When I joined the University of Göteborg in the late 1950s there were four universities in Sweden (see map in fig.1). The oldest one, in Uppsala, was founded in 1477 and the second oldest, in Lund, dates from 1666. Two colleges were located to Stockholm respectively to Göteborg. Both received the status of university in the late 1950s. In addition, there were two technical universities in Stockholm and Göteborg, some specialized colleges connected with agriculture and forestry, one college for odontology, one for veterinary science, and one for each music and art. But the number of students in the whole country was only around 20,000, which meant that only about ten percent of the students leaving the high school (or gymnasium) continued their studies in higher education.

At the end of the 1950s Swedish politicians recognised the need to increase the number of people in higher education, very much influenced by the prevailing conditions in some other European countries and in USA and Japan. The high birth rate from the "baby boom" during the Second World War (see fig 2) was also a strong cause behind the need to expand the numbers in higher education. Even today this "demographic hump" lies behind the need to stimulate students to go into higher education, but particularly, to replace all the people born in the "forties", for many of these persons have started to retire. In addition it is recognised that there are many gaps in public service professions; for example, the government wants to double the number of doctors. In the diagram it can also be seen that the number of births is increasing again, after some years when deaths exceeded births. 
Figure 1: The location of the four universities in Sweden 1960. Source: Statistical Yearbook.

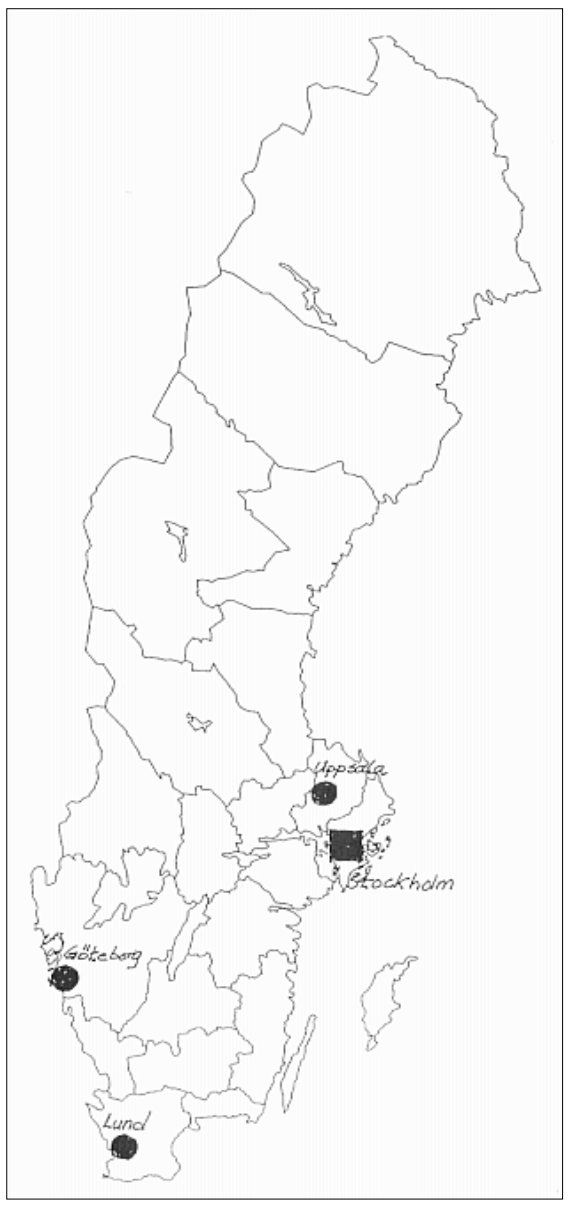

Figure 2: The yearly births in Sweden 1928 - 2002. Source: Statistical Yearbook.

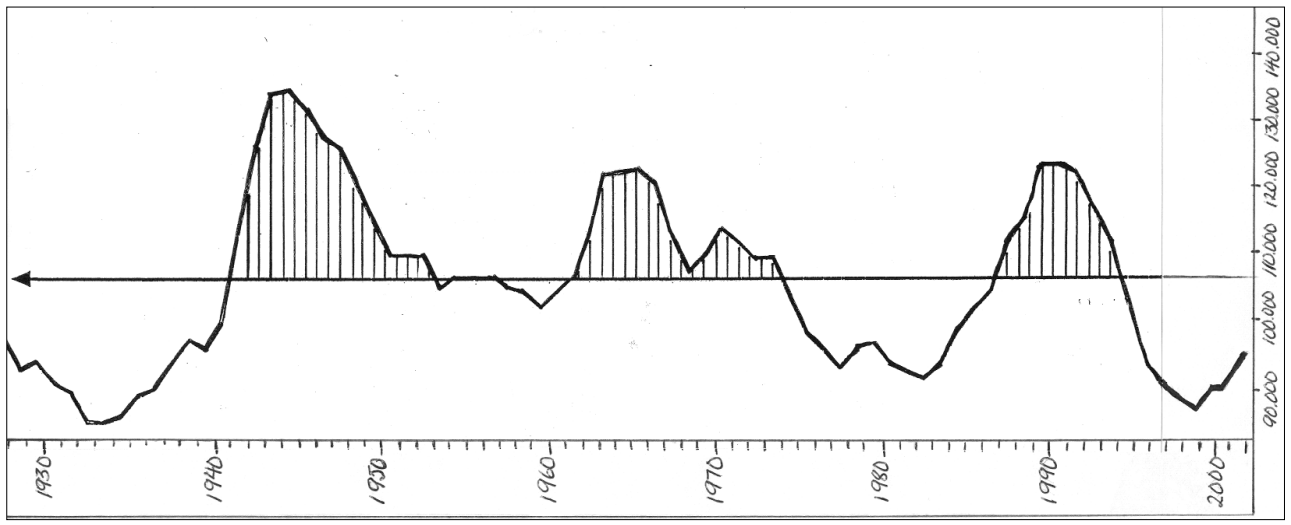


In the early 1960s university expansion became a critical issue for public discussion and policy decisions. A sixth university was established in Umeå as a deliberate regional policy measure, and was the first one located in the northern part of the country. In addition, an influential professor in geography, Sven Godlund, launched the idea of establishing university branches in relevant cities in the country (Dagens Nyheter 3 juli 1964). He argued that it was much better to successively built up higher education in already established universities, rather than investing all the available money in a completely new university. His ideas affected the opinions of many of this report led to the political decision to create five university branches in those cities that were high up in the hierarchy that did not possess universities: Örebro under Uppsala university; Växjö under Lund; Linköping under Stockholm; Karlstad under Göteborg university; and Sundsvall/Härnösand under Umeå university. Linköping was the first one to become university in 1975. Karlstad, Växjö and Örebro followed during the 1990s. The last, Sundsvall/Härnösand/ Östersund, will receive the same status in 2005, but has, as quite many colleges, already the right to pursue postgraduate courses within those research areas where they can show high quality of work. The state government has declared that there will be no more universities in the future but some colleges, e.g., Malmö, would not be content with that decision.

Since 1980 the expansion of higher education has continued and courses at a university level are being developed in more places. Today, Sweden has 13 universities and 23 colleges and, in addition, specialized education of a university character in more than 150 places (see fig. 3). This means that it is possible to take academic courses in 180 places, compared to the four centres in 1950. From the beginning, the idea was to let these colleges to teach on the basic academic level. But as the demand of higher education increased tremendously it was only a question of time before these new colleges or course centres wanted to expand their programmes. The local and regional authorities, firms, organizations, etc., have also given a strong support to the idea of university status. The more researchers, politicians, administrators and other people understood the important role that higher education might generate in a city or region - particularly when different groups could join in common efforts or partnerships - the more the city or region might benefit from the investments. The result today is that in Sweden as a whole there are approximately 300,000 higher education students, which means that about $40 \%$ of students leaving high school (gymnasium) will go to higher studies. But one important locational effect of the geographical diffusion of the availability of higher education is that almost all citizens in Sweden have access to higher education within an one hour travel time from their home.

\section{INCREASED INTERDEPENDANCE IN URBAN SYSTEMS: NEW WINE IN OLD BOTTLES}

An important question that must be asked is whether the expansion of higher education has contributed to increasing urban interdependence over the last few decades, which from a geographical point of view consists of increasing the mutual dependence between places, regions and nations? Undoubtedly, the answer is "yes"! In the process of "place-marketing" 
Figure 3: The location of 13 universities and 23 colleges in Sweden together with a special map of the colleges for business management and administration, art, music, athletics, etc., in Stockholm. It is also possible to follow academic courses in 150 other places.

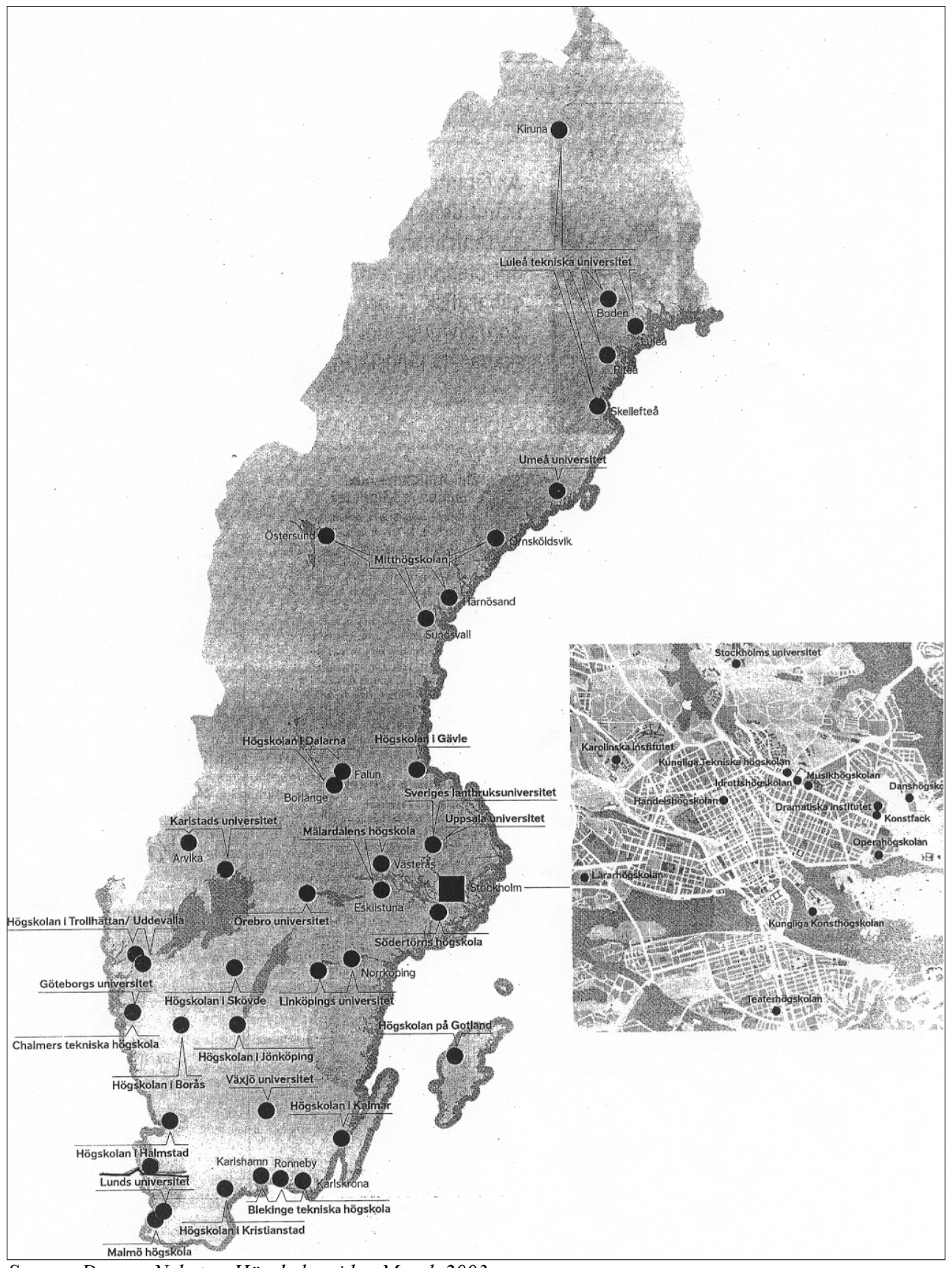

Source: Dagens Nyheter. Högskoleguiden March 2003. 
(see for instance Holcomb 1994) a university or a college may play an important role as an extrovert, expansive activity compared to the obsolete labour-diminishing industries of previous years that are found in many towns. The "entrepreneurial city" identified and studied by researchers such as Harvey (1989) and Boyle and Hughes (1994), usually create new investments in physical infrastructure, science parks, industrial villages, and also bring a rich cultural life to these nodes. In addition, new categories of educated people, academic teachers and students, are added to the cities that possess higher education facilities, and these people also demand other goods and services. Never before have so many new stores, cafés, pubs and restaurants been started in the central parts of these cities to serve the new and often large clientele, thereby altering the urban and economic fabric of the cities and producing a new ambience to life in these places.

The spatial arrangement of higher education is also a source of increasing interdependence between places. There are often exchanges of teachers and supervisors between the academic units concerned, as well as common training and research programmes. In addition, some students have the opportunity to move to other places on a temporary basis to take a special course, whilst other, smaller places may be associated with a university because they are the sites of field centres or special research places. The physical fabric of the university or college city in itself also benefits a lot from the addition of the university facilities. In many cases the new or expanding school-units have taken over abandoned buildings from the army, and these are often centrally located and in very good condition. Finally, increased levels of regional and interregional commuting associated with university students and faculty increases the level of interaction and eventually leads to demands for improved public transport and better highways.

Another important question is whether the classical locational theories- such as central place, with its hierarchical structures, agglomeration economies etc - are still valid for explaining trends in our postmodern, network society. I think, they are! For instance, there is now a need of larger labour market areas because more and more employees are willing to commute larger distances. The number of commuters is still used to determine the borders between these regions and central place ideas are still relevant to explain the patterns, although over a much wider region than before. Agglomeration economies are still as relevant as ever when applied to these new service functions, as they were with industrial activities of the past. Of course, this does not deny that recent studies of urban growth and development have deepened our empirical analyses by collecting completely new kind of data, expanding the operational concepts and models, and broadening the whole framework into more sophisticated social science theories. But, on the whole, the processes of urban growth are the same. This can be illustrated by summarizing the most influential factors that have affected the Swedish urban system during the decades after the Second World War.

\section{CONSEQUENCES FOR THE SWEDISH URBAN SYSTEM}

Although it can be seen that the concept of interdependence is still important in urban systems, it must be accepted that the main driving forces behind increasing interdependence 
have changed over time. All kinds of organizations in society have undergone dramatic changes during the last fifty to sixty years, but some of these organizational changes have had stronger influence on the urban system than others. Although the major changes within public organizations, private industries and non governmental organizations - such as by merging, expanding, or closing down activities etc - are still the most important structuring factors behind interdependence, the reasons for these changes have altered. For example, during the 1950s and 1960s the physical restructuring of society was the most dominant features. The improvement of old urban and economic infrastructures and the rapid construction of residential areas, schools, hospitals and new roads and streets, etc. reinforced the existing urban system tremendously. In some way we can say that, even if the urban system is very old in Sweden, we experienced an era of a new foundation period in the post World War II decades. Within the public and the private sector organizations of all kinds grew and together with the rapid enlargement of the municipalities, created a pattern of increasing interdependence within the urban system. The hierarchical order of the cities was strengthened by the division of the organizations into national, regional and local units and by the fact that many organizations chose to locate in the same cities. Up to the end of 1960s we experienced a kind of domestic hierarchical interdependence in Sweden as a consequence of the construction of the welfare state (Wärneryd 1968, Andersson 1970, Nordström 1971).

The next period, the 1970s, was characterized by the first major stage of urban sprawl. A considerable out-migration from the cities occurred, with rapidly expanding suburbs and commuter villages, especially around the bigger cities. The cities lost considerable numbers of inhabitants as well as shops, smaller industries, offices, etc. The first features of a new urbanized landscape were developed, with new roads and the first external shopping centres. The daily commuting pattern increased substantially around the most attractive labour markets, both in terms of the number of commuters and in the distance between homes and jobs. This period can be named as a phase of urban-rural interdependence, one that was dominated by a symbiotic relation between the city and the surrounding areas.

From the middle of the 1980s we can identify a new shift in the mutual dependence between cities and regions. As has been shown, the number of cities with a new college, or new academic courses, increased tremendously. Many municipalities with decreasing population and deteriorated economy were convinced that their future would be secured if they copied the expanding university cities. The national government also saw the advantage of using academic expansion as a regional policy instrument. It invested in higher education by transferring money to cities with diminishing population, structural problems and growing unemployment, with the aim of reduce the expanding levels of prosperity and growth between the 289 municipalities in the country. Together with the mobilisation of several other interests such as private firms, organizations, individuals etc. and the involvement and co-operation of agencies on the local and regional level a phase of rapid change took place which aided many small and depressed towns (Sörlin \& Törnqvist 2000). It can be argued that never before has a political decision, strongly fostered by many interested and active parts and sponsors on national, regional and local levels, been implemented so quickly in space and time. But in addition the character of higher education and research, with link- 
ages, contacts and exchanges of most kinds, from the local to the global level, has created a new phase in the urban growth process. This might be named as a global-national-local network of interdependence. The concept of glocalization (Robertson 1992 in Urry 2003) may also be relevant since it combines the global with the local. There is no doubt that researchers do not agree upon the signification and meaning of the two basic concepts of the contemporary world, internationalisation and globalisation. But the conditions to which they apply identify an increased mutual dependence between nations and regions in the whole world. Sweden, of course, is one of the most connected countries of the world in this context.

\section{SOME EXAMLPES OF INTERDEPENDANCE}

A rather unsophisticated, but still comprehensive summary of the increased interdependence in the Swedish urban system can be seen in recent population trends. Out of the 39 university or college cities (localities) or cities with a higher education campus, 25 had an increase in population of around 2.9 percent between $1995-2000$. The other 14 centres lost on average of 2.3 percent. Most of these latter localities are either located in the northern part of Sweden, or are still suffering of an obsolete industrial structure. In general, the localities that have grown have received a younger population, thanks to the incoming students. Other cities that do not have a university or college, but which have gained inhabitants during the same period, are either within the hegemony of an expanding regional labour market or are located on the attractive west coast of the country. As seen in figure 2 the number of students will oscillate over time and already some colleges, particularly, in sparsely populated areas have trouble in filling up their quota of students.

Another way of showing the consequences of higher education for the city is by identifying the role of the money from the State in economic terms. For example, in Umeå, a city of 7,995 inhabitants in the year 2000, around ten percent of the labour market and more than two billion Swedish Krona (approximately 270 millions in US dollars) are dependent on this external support for higher education (Lindgren \& Marklund 1995).

A third way of showing the importance of the higher education sector upon the urban system is to look at the case of Eskilstuna, southwest of Stockholm. Once a pure Industrial city of around 90,000 inhabitants, it has gone from a loss of about $500-600$ people per year a decade or more ago, to a positive surplus of more than 1,000 persons in 2002 . Its demographic and employment situation was changed by locating a college in the city, and by creating much better communication links with Stockholm. Families in Stockholm could buy a nice house for a fourth of the price in Stockholm, could enjoy great natural conditions, almost within walking distance, and were still able to maintain the job in the capital city. For the families already living in Eskilstuna the reverse of these gains occurred, through increasing house prices and thereby higher property taxation value. The consequences are that these families, or newly started families in the city with lower household income, now have to look for houses outside the city, to the even smaller places around the city! Although the consequences of these changes are mostly positive, it cannot be denied 
that there are growing negative effects in addition to higher house prices, associated with social, ethnical and economical segregation within cities.

A fourth trend that needs to be noted is that clustering is increasing between the universities and colleges. As in Great Britain, many of the Swedish smaller colleges and even some universities, attempt to solve the problems of size and specialisation by cooperating more closely to fill in gaps in their curriculum. This is achieved in several ways: by providing co-ordinated courses; by identifying distinctive profiles of their own (mostly connected with the business character in the city or region); by participation in more networks within both teaching and research; by getting more active in the keen competition for research money; by attracting well-known researchers to their campuses in order to build up an excellent research milieu, even perhaps of Nobel Prize quality. One of the most significant of these trends can be seen in the Öresund region, that includes Zealand in Denmark and Skåne in Sweden. An Öresund university framework has been established, involving 13 universities and colleges and around 120,000 students, with cooperation between special programmes and research areas. The aim is, of course, to compete with the best universities in the Europe.

All the mentioned trends so far may be named "happy trends", as they maintain the size and quality of higher education and research in Sweden and also act as a salvation for the growth of both the country and for the cities and towns that possess universities and colleges. But there seems little doubt that there are also "unhappy trends" to this growth. The most pessimistic voices in the debate argue that there will be a "hangover period" produced by a too rapid expansion of higher education and this is just waiting around the corner. The quality of both teaching and research is declining, and the problem of recruiting good teachers to many of the smaller colleges has led to the development of A- and B-centres. As a result, many sponsors do not feel that they get good value for their invested money. If they reduce the size of their contribution the some of the smaller and less productive places will lose out even further. This may create a sector of poor or less attractive colleges which will have less growth potential upon the centres in which they are located. If this does happen, then we might see the operation of the familiar diseconomies of agglomeration in this sector.

\section{CONCLUSION}

This study has shown that the urban system is once again saved by an expanding phenomenon - this time it is higher education and research. More actors and more partnerships together with a common belief in the blessing of the knowledge as the sacrificing mean in society have speed up the process. A new landscape of prosperity has grown up rather fast. So, is everything is all right? We must be cautious about a positive or rather a permanent conclusion!

In their study of higher education as a means to sustainable development in marginal regions Andersson and Blom (2002) argue the important role of higher education of fostering this kind of development, but they also warn for the implications in a longer perspective. Even if the partnership in the region gives strong support to the start of higher educa- 
tion there are still quite many people outside what is taken place and the barriers are many. So, how can we support and adjust higher education to changing demands, both within the system in itself and in society? Can we discern the next phase of urban growth and development? How do we facilitate what Urry (op.cit., p. 37) argued is fundamental to development: what combinations of mobility and moorings are needed for a complex system to develop in the social world.

So far it has been shown that the Swedish urban system has been characterised by three phases: domestic hierarchical interdependence (1945 - 1970), urban-rural symbiosis interdependence (1970-1985), and global-national-local network of interdependence (1985- ) These provide a broad and simplified characterization of the growth and change of the Swedish urban system has been given (fig.4) . But the recent changes suggest that a new phase is underway, linked to the still dominant opinions about the positive changes that the expansion of higher education have brought to cities and there are numerous ideas of how to create attractive conditions to maintain inhabitants in a city and to entice students. Most people do not want to see the addition of a new college simply as some type of compensation for a closed-down industry; instead they see it as an important economic and social injection for the whole municipality or region. So, we must also recognise that the city is increasingly taking on the form of a hyper-complex organisation, composed of individuals, firms, schools, societies, clubs, cafés, restaurants, museums, etc, and the attractive place for spatial arrangement of all these assets. A university or college fits very well into this context. The professors, administrators and students both demand and stimulate a rich cultural and social life by taking active part in most what is happening. This in turn means that fewer cities define themselves with respect to economic, industrial or export terms but want to market the special climate and atmosphere that a university can bring to a place, and to recognise that it is one that is linked to more than just the region or the nation. Indeed the latest phase of interdependence and relationships between cities and the outside world may be close to what Urry calls "cosmopolitan interdependence" (op.cit.,p.132 ff). This "...involves the capacity to live simultaneously in both the global and the local, in the distant and proximate, in the universal and the particular" (p.137). Even if I separate them, the cosmopolitanism is already here, influencing our daily life more and more, particularly our personal interests, cultural choices, hobbies and so on. These interests may govern where and how we want to live, work, travel, eat, read, etc. The same kind of exodus from the larger cities during the 1970s may be seen but on a very different geographical scale and with more temporary and even movements through the use of the new interaction devices such as the internet. Perhaps the most exciting implication of this development for the coming decades has been given by the Nobel prize winner, Joseph Rotblat (see Urry 2003 p.97). He suggested that: "It is global interdependence between the world's population that is the key to developing a universalist allegiance to 'humanity' rather than to national identities".

Although universities have always had this universal role - or at least a continental role when the rest of the world was not known, as seen by the use of Latin in ancient European universities - they were small and largely peripheral in society. In recent decades, the increased numbers in higher education, their economic importance in cities, and their linka-ges 
to the general world of ideas ensure that universities and colleges are playing an impor-tant role in this transition.

Figure 4: Changing interdependence in the urban systems

\begin{tabular}{|llll|}
\hline $\begin{array}{l}\text { Kind of } \\
\text { interdepen- } \\
\text { dence }\end{array}$ & Time & $\begin{array}{l}\text { Driving } \\
\text { force }\end{array}$ & $\begin{array}{l}\text { Consequences } \\
\text { for urban } \\
\text { system }\end{array}$ \\
$\begin{array}{l}\text { Domestic } \\
\text { hierarchical }\end{array}$ & -1970 & $\begin{array}{l}\text { Organization } \\
\text { of infrastructure }\end{array}$ & $\begin{array}{l}\text { Cities higher } \\
\text { up in the } \\
\text { hierarchy }\end{array}$ \\
$\begin{array}{l}\text { Urban-rural } \\
\text { symbiosis }\end{array}$ & $1970-$ & $\begin{array}{l}\text { Public service } \\
\text { of all kind }\end{array}$ & $\begin{array}{l}\text { All municipa- } \\
\text { lities }\end{array}$ \\
$\begin{array}{l}\text { Global-national } \\
\text {-local }\end{array}$ & $1985-$ & $\begin{array}{l}\text { Higher } \\
\text { education and } \\
\text { research }\end{array}$ & $\begin{array}{l}\text { Pattern from } \\
1950 \text { s repeats } \\
\text { itself }\end{array}$ \\
& & & \\
Cosmopolitan & $2010 ?$ & Interest (hobby) & $\begin{array}{l}\text { All municipa- } \\
\text { lities }\end{array}$ \\
\hline
\end{tabular}

\section{References}

Andersson, L., 1970: Rumsliga effekter av organisationsförändringar. Meddelanden från Göteborgs Universitets Geografiska Institutioner. Serie B, 17, Göteborg.

Andersson, L, \& Blom, T., 2002: Higher Education as a Means to Sustainable Development in Marginal Regions. In Jussila, H., Majoral, R. \& Cullen, B. (eds) Sustainable development and Geographical Space. Issues of Population and Education in Marginal Areas. Ashgate Publishing Limited. Aldershot, England.

Blom, T., 1996: Perspektiv på kunskap och utveckling. Om attityder till högskoleutbildning i några perifera regioner. Meddelanden från Göteborgs Universitets Geografiska Institutioner. Serie B, 89, Götenorg.

Boyle, M. \& Hughes, G., 1994: The Politics of Urban Entrepreneurialism in Glasgow. Geoforum 25, p. $453-470$.

Godlund, S., 1964: Universitetens utbyggnad. Dagens Nyheter 3 juli 1964.

Harvey, D., 1989: From Managerialism to Entrepreneurialism: The Transformation in Urban Governance in Late Capitalism. Geografiska Annaler 71B, p. 3 - 17

Holcomb, B., 1994: City Make-Overs: Marketing the Post-Industrial City. In Place Promotion. The Use of Publicity and Marketing to Sell Towns and regions, Gold, J. R. \& Ward, S. V. (eds) John Wiley, Chichester, p. $115-131$. 
The Dictionary of Human Geography. Southampton 1983.

Högskoleguiden, 2003: Dagens Nyheter, Stockholm.

Lindgren \& Marklund, 1995: Universitetets ekonomiska betydelse för Umeå kommun. In Samhällseffekter av Umeås universitet, (eds. Holm, E. \& Wiberg, U.). Cerum, Umeå University.

Nordström, L., 1971: Rumsliga förändringar och ekonomisk utveckling. Meddelanden från Göteborgs Universitets Geografiska Institutioner, Ser. B, Nr. 23, Göteborg.

Nordström, L., 1977: Population Changes in a Functional Regional System. In Economic Geography, Vol. 53, No. 2.

Robertson, R., 1992: Globalization: Social Theory and Global Culture. London. Sage.

Sörlin, S. \& Törnqvist, G., 2000, Kunskap för välstånd. Universiteten och omvandlingen av Sverige. SNS förlag, Kristianstad.

Urry, J., 2003: Global Complexity. Polity. Cornwall.

Wärneryd, O., 1968: Interdependence in Urban System. Meddelanden från Göteborgs Universitets Geografiska Institutioner, Ser. B, Nr. 1, Göteborg.

Young, O. R., 1964: A Survey of General Systems Theory. General Systems, Vol. IX. 